\title{
WHY CLEAN COOKING PROGRAMS FAIL AMONG RURAL WOMEN? A FEMALE USER- CENTERED VIEW FROM UTTAR PRADESH, INDIA
}

\author{
Wang J \\ Independent Researcher, China
}

\begin{abstract}
Many clean cooking programs around the world have invested in women to lead in the transition to cleaner cookstoves. However, in rural India, the lack of uptake from women is a major problem that has undermined the success of programs which expect women to act as champions of clean cookstoves in their community. To inform the theory of change of women-centered clean cooking programs and support future policymaking and programming in this field, this paper aims to address the knowledge gap on consumers' - and especially women's - attitude, knowledge and choice behavior towards improved cookstoves. In this paper, I use data from the ACCESS survey, collected in 2015 in Uttar Pradesh, to generate further gender-disaggregated evidence on the roles played by health impact awareness, intra-household power dynamics and access to finance on rural women's behavior towards improved biomass cookstoves (IBCS). I identify the two most important shapers of women's choice behavior towards IBCS as 1) level of satisfaction with traditional biomass cookstoves and 2) previous awareness and experience of IBCS. I find that Uttar Pradesh women are at once more unsatisfied with traditional unimproved biomass cooking practice, and more aware of IBCS technology. Whereas the former has a significant and positive effect in driving women towards adoption of IBCS, I find the latter in fact not only fails to mobilize demand but also undermines willingness to pay by about $40 \%$ on average. Through gender-lens market research in the improved biomass cookstoves market, this paper builds upon the evidence base for the design of more successful women-focused clean cooking programs.
\end{abstract}

Keywords: clean cooking, women's health, rural environmental health, women's consumption behavior, clean technology adoption

\section{Introduction}

A growing body of literature has explored women's potential in driving Improved Biomass Cookstove (IBCS) adoption in rural areas of developing countries (Hart \& Smith 2013; Shankar et al. 2015; Mohapatra and Simon 2017). This expectation arises first because in developing countries, rural women are the primary cooks and cooking fuel gatherers in their households. Therefore, they could be more susceptible to cleaner, more fuel-efficient cookstoves which offers superior welfare and economic gains (Dasgupta et al. 2004: 5; Person et al. 2012: 1566; Barnes et al. 1994: 8) and better outcomes on their own health (Millar and Mobarak 2013). Another rationale for such expectation is that as primary caretakers of their family, rural women have stronger incentive to invest in their children's health than men (Duflo 2003; Duflo \& Udry 2003), which is the most at risk from unimproved cookstove emissions apart from women's own health (Baumgarten et al. 2011; Yu 2011). 
Rural India is a vital testing ground for women-focused government programs promoting clean cookstoves, where nearly $80 \%$ of households use biomass as the primary cooking fuel (Seghal et al. 2014). As a prominent example, in 2009, the Ministry of New and Renewable Energy in India implemented the National Biomass Cookstove Initiative which specifically targeted pregnant women as both beneficiaries and change agents by introducing advanced combustion biomass stoves through the antenatal care system (Mukhopadhyay et al. 2012: 2; Pal \& Rehman 2008).

While there is strong empirical support for establishing women as beneficiaries of clean cooking, there is a lack of evidence to support the assumption that women could act as effective agents for change in the transition to clean cookstoves by championing adoption of improved cookstove products, simply because they are the primary victims. In practice, the expectation for women to act as clean cookstove advocates has often failed. Various studies have shown that women in developing countries often do not display strong preference for shifting to IBCS as expected by programs and policy (Millar and Mobarak 2013; Khandelwal 2017). Without knowing the causes of this lack of interest in uptake, it is impossible for policymakers and development practitioners to improve or scale up such women-centered programs for clean cookstoves. Hence, this paper aspires to produce more rigorous evidence on the driver and inhibitors of IBCS adoption among women by looking at rural India as an important sample.

Using results of the ACCESS Survey conducted by Columbia University researchers in 2015 (Aklin et al. 2016) in Uttar Pradesh, India's largest state, this paper attempts to contribute to the knowledge gap on low demand from rural Indian women for IBCS, in particular in a scenario where these women already have particularly negative perceptions of traditional unimproved cookstoves. Filling this knowledge gap is vital for informing policymakers and program implementers on how to improve outcomes of clean cooking energy programs.

The analysis conducted in this paper is product-agnostic. The survey questionnaire does not specify the type of clean cookstoves when interviewees are questioned about their attitudes and preferences. Therefore, this paper is not a market research study for any particular cookstove product or company, but rather focuses on the viability of currently available improved biomass cookstoves as a whole market. By setting such a focus, this paper aims to ameliorate the current paucity of gender-lens market research in the improved biomass cookstoves market, which is important in building the evidence base to support the theory of change of clean cooking programs which relies on women as agents of change.

\section{Literature Review and Hypotheses}

Existing literature which analyzes user behavior towards IBCS in developing countries have broadly focused on the following drivers of decisions:

1) Perceived health benefits: Reduced disease burden costs is the basis argument of many scholars who study incentives for adoption of improved cookstoves, such as Malla et al. (2011). Several studies on improved cookstove adoption in rural India have also cited the lack of knowledge of the health risks associated unimproved cookstoves as a barrier to adoption (Alam et al. 2016; Kumar et al. 2016) 
2) Intra-household structure for decision-making - Millar and Mobarak (2013, p.3) found that gender determines the allocation of decision-making power within a household, and women's stronger preference for improved stoves compared to their husbands' fail to translate to adoption because they are overruled by male authority

3) Access to finance - Rosenbaum et al. (2015) found that most users would not pay for the IBCS distributed for study but prefer keeping it to receiving a cash buy-out, which shows preference for IBCS adoption when financial barriers to acquisition are eliminated; Millar and Mobarak (2013, p.3) found although women do develop preference for healthier stoves, they would not act on it when a small price was charged, indicating the significance of financial constraints in women's choice behavior towards IBCS.

4) Product attributes which either encourage or deter adoption, such as portability (Rehfuess et al. 2014), (mis)fit with cultural or taste preferences (O'Dell et al 2013; Malla \& Timilsina 2014, p.15), and aesthetic appeal (Troncoso et al. 2007).

These broad thematic areas form the basis of the four key hypotheses which this paper will investigate using data from the Access survey (Table 1). It should be noted that among the drivers of choice behavior discussed, most are gender-agnostic. But there are two ways women's low demand for IBCS could be explained: First, by focusing on direct effects of the female identity, which is the case within the theme of intra-household power; Second, by establishing if women have fewer of the driver conditions for adoption, or face more of the barriers that hinder adoption, either of which indirectly leads to lower demand among women. The latter approach guides my analysis in the rest of the themes.

Table 1. Key themes and hypotheses.

\begin{tabular}{llll}
\hline$\#$ & Theme & Hypothesis & Key Survey Metrics in Survey \\
\hline 1 & Health & $\begin{array}{l}\text { Women's low demand for IBCS results } \\
\text { from a lack of awareness of health impacts } \\
\text { of unimproved cookstoves OR inability to } \\
\text { link that assessment to demand of IBCS }\end{array}$ & $\begin{array}{l}\text { Satisfaction with current (unimproved) } \\
\text { cooking arrangement } \\
\text { Assessment of health impact of current } \\
\text { (unimproved) cooking arrangement }\end{array}$ \\
\hline 2 & Power & $\begin{array}{l}\text { Women's low demand for IBCS results } \\
\text { from the intra-household distribution of } \\
\text { decision-making power which inhibits } \\
\text { women from occupying positions that have } \\
\text { a say in IBCS adoption }\end{array}$ & $\begin{array}{l}\text { Household headship } \\
\text { Female headship } \\
\text { Male headship }\end{array}$ \\
\hline 3 & Finance & $\begin{array}{l}\text { Women's low demand for IBCS results } \\
\text { from lack of access to finance to fund the } \\
\text { purchase }\end{array}$ & $\begin{array}{l}\text { Household expenditure } \\
\text { Household savings } \\
\text { Household indebtedness } \\
\text { Bank account ownership }\end{array}$ \\
& & & Awareness of IBCS \\
\hline 4 & Product & $\begin{array}{l}\text { Women's low demand for IBCS results } \\
\text { from flaws of the IBCS products of which } \\
\text { they have become aware }\end{array}$ & Usage experience of IBCS \\
& & &
\end{tabular}




\section{Materials and Methods}

The ACCESS dataset was the result of fieldwork conducted in Uttar Pradesh in 2015 by a group of Columbia University researchers in collaboration with the Delhi-based think tank Council on Energy, Environment and Water. The original ACCESS dataset has 3023 observations collected in 18 districts of the state.

For the purpose of this paper, I only focus on those who currently use biomass as a primary cook fuel since those who mainly use LPG $(n=498)$ or other sources of fuel $(n=30)$ would not be expected to shift to adopt IBCS. The filtered dataset is summarized as follows:

Table 2. ACCESS dataset (biomass subset used) summary.

\begin{tabular}{|c|c|}
\hline Feature & Description \\
\hline Sample size & 2495 \\
\hline Interest in IBCS & $\begin{array}{l}33.2 \% \text { Interested } \\
66.8 \text { Not interested }\end{array}$ \\
\hline $\begin{array}{l}\text { Interest in IBCS } \\
\text { (Female respondents only) }\end{array}$ & $\begin{array}{l}32.7 \% \text { Interested } \\
67.3 \% \text { Not interested }\end{array}$ \\
\hline Willingness to pay for IBCS (rupees) & $\begin{array}{l}\text { Range: 0-800 | 40-800 among interested } \\
\text { Mean: } 58.4 \mid 175.9 \text { among interested } \\
\text { Median: } 0 \mid 100 \text { among interested }\end{array}$ \\
\hline $\begin{array}{l}\text { Willingness to pay for IBCS (rupees) } \\
\text { (Female respondents only) }\end{array}$ & $\begin{array}{l}\text { Range: 0-800 | 50-800 among interested } \\
\text { Mean: } 58.8 \mid 179.6 \text { among interested } \\
\text { Median: } 0 \mid 100 \text { among interested }\end{array}$ \\
\hline Respondent identity & $\begin{array}{l}69.4 \% \text { Head of } \mathrm{HH} \\
30.6 \% \text { Other members of } \mathrm{HH}\end{array}$ \\
\hline Respondent gender & $\begin{array}{l}82.5 \% \text { Male } \\
17.5 \% \text { Female }\end{array}$ \\
\hline Education level of head of $\mathrm{HH}$ & $\begin{array}{l}36.5 \% \text { No formal schooling } \\
35.7 \% \text { Up to } 5 \text { th standard } \\
21.6 \% \text { Up to } 10 \text { th standard } \\
15.0 \% 12 \text { th standard or diploma } \\
12.3 \% \text { Graduate and above }\end{array}$ \\
\hline Religion & $\begin{array}{l}88.9 \% \text { Hindu } \\
11.0 \% \text { Muslim } \\
0.1 \% \text { Other }\end{array}$ \\
\hline Caste & $\begin{array}{l}\text { 79.4\% Scheduled Caste/Tribe } \\
\text { and Other backward classes } \\
20.6 \% \text { Non-scheduled }\end{array}$ \\
\hline Primary Cook Fuel Source & $\begin{array}{l}63.8 \% \text { Firewood } \\
36.2 \% \text { Dung cake }\end{array}$ \\
\hline Grid-electricity connection* & $\begin{array}{l}58.2 \% \text { Connected } \\
41.8 \% \text { Not connected }\end{array}$ \\
\hline
\end{tabular}

*A substantial proportion of households connected to grid-electricity continue to cook with traditional non-electrical biomass cookstoves 
This paper considers two aspects of choice behavior towards IBCS - interest and willingness to pay (WTP), both of which was coded as a question in the survey. Interest was registered as a binary variable, and willingness to pay was a continuous price figure gauged using the contingent evaluation method1. I treat the WTP of all respondents who are not interested as 0 for all analysis in this paper.

I use the following logistic regression equation to estimate interest:

Equation 1. Logistic regression estimator equation for interest in IBCS.

$\operatorname{Pr}($ Interest $)=\frac{1}{1+e^{-\left(\beta_{0}+\sum \beta_{k} X_{k, v h i}\right)}}$

Where Error! Reference source not found.

Table 3 explains what each variable measures:Error! Reference source not found.

Table 3. Independent Variables.

\begin{tabular}{|c|c|c|c|c|c|}
\hline Variable & Notes & Variable & Notes & Variable & Notes \\
\hline \multicolumn{2}{|c|}{ 1st Cohort: Respondent characteristics } & \multicolumn{2}{|c|}{ 2nd Cohort: Household characteristics } & \multicolumn{2}{|c|}{ 3rd Cohort: Household finances } \\
\hline Fem $_{v h i}$ & $\begin{array}{l}\text { Whether respondent is } \\
\text { female }\end{array}$ & $E d u_{v h}$ & $\begin{array}{l}\text { Education level of } \\
\text { head of } \mathrm{HH}\end{array}$ & $\operatorname{Exp}_{v h}$ & $\begin{array}{l}\text { Monthly expenditure } \\
\text { of HH (in rupees) }\end{array}$ \\
\hline Head $_{v h i}$ & $\begin{array}{l}\text { Whether respondent is } \\
\text { head of } \mathrm{HH}\end{array}$ & $\operatorname{Hin}_{v h}$ & $\begin{array}{l}\text { Whether } \mathrm{HH} \text { is } \\
\text { Hindu }\end{array}$ & $\operatorname{Exp}^{\wedge} \mathbf{2}_{v h}$ & $\begin{array}{l}\text { Quadratic of monthly } \\
\text { expenditure of HH }\end{array}$ \\
\hline Fem_Head $_{v h}$ & $\begin{array}{l}\text { Whether respondent is a } \\
\text { female head of } \mathrm{HH}\end{array}$ & Caste $_{v h}$ & $\begin{array}{l}\text { Whether } \mathrm{HH} \text { is a } \\
\text { scheduled caste }\end{array}$ & Saving $_{v h}$ & $\begin{array}{l}\text { HH saving in the last } \\
\text { year (in rupees) }\end{array}$ \\
\hline IBCSaware $_{\text {vhi }}$ & $\begin{array}{l}\text { Whether respondent has } \\
\text { heard of IBCS before } \\
\text { survey }\end{array}$ & No_Adults $v_{v h}$ & $\begin{array}{l}\text { Number of adults in } \\
\text { the HH }\end{array}$ & Bank $_{v h}$ & $\begin{array}{l}\text { Whether anyone in } \\
\text { HH has a bank } \\
\text { account }\end{array}$ \\
\hline IBCSuse $_{v h i}$ & $\begin{array}{l}\text { Whether respondent has } \\
\text { used IBCS before } \\
\text { survey }\end{array}$ & No_Child ${ }_{v h}$ & $\begin{array}{l}\text { Number of children } \\
\text { in the } \mathrm{HH}\end{array}$ & Debt $_{v h}$ & $\begin{array}{l}\text { Whether } \mathrm{HH} \text { is } \\
\text { indebted }\end{array}$ \\
\hline \multicolumn{6}{|c|}{$\begin{array}{c}\text { Whether respondent } \\
\text { Healthasses }_{\text {vithinks unimproved }} \\
\text { cookstove has an } \\
\text { impact on his/her health }\end{array}$} \\
\hline Satisf $y_{v h i}$ & $\begin{array}{l}\text { Whether respondent is } \\
\text { unsatisfied with current } \\
\text { cooking arrangement }\end{array}$ & & & & \\
\hline Avail $_{v h i}$ & $\begin{array}{l}\text { Whether respondent is } \\
\text { unsatisfied with current } \\
\text { cooking fuel }\end{array}$ & & & & \\
\hline
\end{tabular}

${ }^{1}$ For those who have not heard of IBCS before the taking the survey, the enumerator reads to the respondent the following text: "Improved biomass cookstoves use biomass fuel for cooking. They burn biomass more efficiently than traditional stoves, reducing fuel use and smoke." The respondent is then expected to express interest and in case interested, report a willingness-to-pay figure based on understanding of this brief description. (questionnaire p.18) 
I use the following OLS equation to estimate the willingness-to-pay figure:

Equation 2. OLS regression estimator equation for WTP for IBCS.

\section{Error! Reference source not found.}

Peer behavior within social networks has been shown to be an influential factor in promoting improved cookstove adoption in rural India (Bhojvaid et al 2014). To account for this, I also ran the same logistic and OLS regressions with fixed effects at village level (Error! Reference source not found. to give alternative estimates of the coefficients once the effect of social networks is included.

Table 4: Estimates from Logistic Regression on Interest and OLS regression with Willingness to Pay

\begin{tabular}{|c|c|c|c|c|}
\hline & Interest & & Willingness to & \\
\hline Variable & $\begin{array}{l}\text { Logistic } \\
\text { Regression }\end{array}$ & $\begin{array}{l}\text { Logistic Regression } \\
\text { with Fixed Effects }\end{array}$ & $\begin{array}{l}\text { OLS } \\
\text { Regression }\end{array}$ & $\begin{array}{l}\text { OLS Regression } \\
\text { with Fixed Effects }\end{array}$ \\
\hline Fem $_{v h i}$ & $\begin{array}{l}0.15 \\
(-0.30)\end{array}$ & $\begin{array}{l}0.24 \\
(0.21)\end{array}$ & $\begin{array}{l}11.51 \\
(15.72)\end{array}$ & $\begin{array}{l}10.13 \\
(8.79)\end{array}$ \\
\hline$E d u_{v h}$ & $\begin{array}{l}-0.03 \\
(0.038)\end{array}$ & $\begin{array}{l}-0.028 \\
(0.047)\end{array}$ & $\begin{array}{l}0.23 \\
(1.94)\end{array}$ & $\begin{array}{l}0.21 \\
(1.95)\end{array}$ \\
\hline $\operatorname{Hin}_{v h}$ & $\begin{array}{l}-0.00038 \\
(0.14)\end{array}$ & $\begin{array}{l}0.098 \\
(0.19)\end{array}$ & $\begin{array}{l}-1.57 \\
(7.10)\end{array}$ & $\begin{array}{l}6.35 \\
(8.02)\end{array}$ \\
\hline Caste $_{v h}$ & $\begin{array}{l}-0.14 \\
(0.11)\end{array}$ & $\begin{array}{l}-0.32 * * \\
(0.15)\end{array}$ & $\begin{array}{l}-5.32 \\
(5.69)\end{array}$ & $\begin{array}{l}-10.19 * \\
(6.14)\end{array}$ \\
\hline Head $_{v h i}$ & $\begin{array}{l}0.24 * \\
(0.13)\end{array}$ & $\begin{array}{l}0.19 \\
(0.15)\end{array}$ & $\begin{array}{l}10.83^{*} \\
(6.32)\end{array}$ & $\begin{array}{l}4.20 \\
(6.24)\end{array}$ \\
\hline Fem_Head ${ }_{v h}$ & $\begin{array}{l}-0.021 \\
(0.26)\end{array}$ & $\begin{array}{l}0.0021 \\
(0.32)\end{array}$ & $\begin{array}{l}-5.24 \\
(13.52)\end{array}$ & $\begin{array}{l}-0.38 \\
(13.30)\end{array}$ \\
\hline No_Adults ${ }_{v h}$ & $\begin{array}{l}-0.0028 \\
(0.021)\end{array}$ & $\begin{array}{l}0.014 \\
(0.027)\end{array}$ & $\begin{array}{l}0.86 \\
(1.10)\end{array}$ & $\begin{array}{l}1.44 \\
(1.09)\end{array}$ \\
\hline No_Child ${ }_{v h}$ & $\begin{array}{l}-0.011 \\
(0.022)\end{array}$ & $\begin{array}{l}-0.037 \\
(0.027)\end{array}$ & $\begin{array}{l}0.61 \\
(1.14)\end{array}$ & $\begin{array}{l}-0.50 \\
(1.13)\end{array}$ \\
\hline $\operatorname{Exp}_{v h}$ & $\begin{array}{l}-0.000024 \\
(0.000022)\end{array}$ & $\begin{array}{l}-0.0000069 \\
(0.000028)\end{array}$ & $\begin{array}{l}-0.00030 * * * \\
(0.0011)\end{array}$ & $\begin{array}{l}-0.0014 \\
(0.0012)\end{array}$ \\
\hline $\operatorname{Exp}^{\wedge} 2_{v h}$ & $\begin{array}{l}0.00000000061 \\
(0.00000000067)\end{array}$ & $\begin{array}{l}0.00000000071 \\
(0.00000000082)\end{array}$ & $\begin{array}{l}0.000000088 * \\
* \\
(0.000000036)\end{array}$ & $\begin{array}{l}0.000000068^{*} \\
(0.000000036)\end{array}$ \\
\hline Saving $_{v h}$ & $\begin{array}{l}0.0000018 \\
(0.0000021)\end{array}$ & $\begin{array}{l}0.00000010 \\
(0.0000029)\end{array}$ & $\begin{array}{l}0.00026 * * \\
(0.00011)\end{array}$ & $\begin{array}{l}0.00018 * \\
(0.00010)\end{array}$ \\
\hline Bank $_{v h}$ & $\begin{array}{l}-0.011 \\
(0.18)\end{array}$ & $\begin{array}{l}0.13 \\
(0.22)\end{array}$ & $\begin{array}{l}21.66 * * \\
(9.36)\end{array}$ & $\begin{array}{l}22.51 * * \\
(9.35)\end{array}$ \\
\hline $\operatorname{Debt}_{v h}$ & $\begin{array}{l}0.084 \\
(0.089)\end{array}$ & $\begin{array}{l}0.086 \\
(0.12)\end{array}$ & $\begin{array}{l}0.46 \\
(4.60)\end{array}$ & $\begin{array}{l}10.65 * * \\
(4.87)\end{array}$ \\
\hline
\end{tabular}




\begin{tabular}{|c|c|c|c|c|}
\hline IBCSaware $_{v h i}$ & $\begin{array}{l}-0.66 * * * \\
(0.12)\end{array}$ & $\begin{array}{l}-0.62 * * * \\
(0.15)\end{array}$ & $\begin{array}{l}-24.03 * * * \\
(5.92)\end{array}$ & $\begin{array}{l}-13.33 * * \\
(6.00)\end{array}$ \\
\hline IBCSuse $_{v h i}$ & $\begin{array}{l}-1.45^{* * * *} \\
(0.48)\end{array}$ & $\begin{array}{l}-1.65 * * * \\
(0.52)\end{array}$ & $\begin{array}{l}-30.56^{* * *} \\
(13.97)\end{array}$ & $\begin{array}{l}-37.59 * * * \\
(14.12)\end{array}$ \\
\hline Healthassess $_{\text {vhi }}$ & $\begin{array}{l}-0.0035 \\
(0.11)\end{array}$ & $\begin{array}{l}-0.10 \\
(0.15)\end{array}$ & $\begin{array}{l}7.94 \\
(5.75)\end{array}$ & $\begin{array}{l}4.03 \\
(6.00)\end{array}$ \\
\hline Satisf $y_{v h i}$ & $\begin{array}{l}0.31 * * * \\
(0.12)\end{array}$ & $\begin{array}{l}0.37 * * \\
(0.15)\end{array}$ & $\begin{array}{l}20.57 * * * \\
(6.06)\end{array}$ & $\begin{array}{l}21.35^{* * * *} \\
(6.04)\end{array}$ \\
\hline Avail $_{v h i}$ & $\begin{array}{l}-0.0059 \\
(0.13)\end{array}$ & $\begin{array}{l}-0.22 \\
(0.16)\end{array}$ & $\begin{array}{l}23.76 * * * \\
(6.57)\end{array}$ & $\begin{array}{l}9.46 \\
(6.68)\end{array}$ \\
\hline
\end{tabular}

Notes:

For each outcome variable, I report the coefficients of interest and their standard errors in parentheses.

Notations on statistical significance: *significant at $90 \%$ confidence level; **significant at $95 \%$ confidence level;

$* * *$ significant at $99 \%$ confidence level

\section{Results and Discussion}

I specifically focus on one phenomenon revealed by the ACCESS survey - although women in Uttar Pradesh are more unsatisfied on average with unimproved biomass cookstoves than men, they do not show stronger interest or willingness to pay for improved biomass cookstoves. I seek to explain this phenomenon by conducting analysis on four themes: health, power, finance and product. I use logistic and OLS regressions on interest and willingness to pay (WTP) respectively to obtain coefficient estimates for a group of variables which address each of the four themes, and compare my findings from data analysis to existing literature on drivers and inhibitors of women's adoption of IBCS. My findings concur with previous literature in the findings that women under-assess negative health impacts of traditional biomass cookstoves, have relative disadvantage in access to credit and have less likelihood of being heads of households; however, my analysis does not find these factors to be the driving causes of low adoption among women. Instead, I identify and seek to explain a surprising but highly significant finding - previous awareness of IBCS exerts significant and negative effect on interest and WTP.

\section{Health}

Data from the ACCESS survey indicates that Uttar Pradesh women under-assess the health impacts of unimproved cookstoves on themselves. In fact, they are slightly less aware of the health risks associated than men (Graph 1), despite spending more time around the cookstove as primary cooks. 


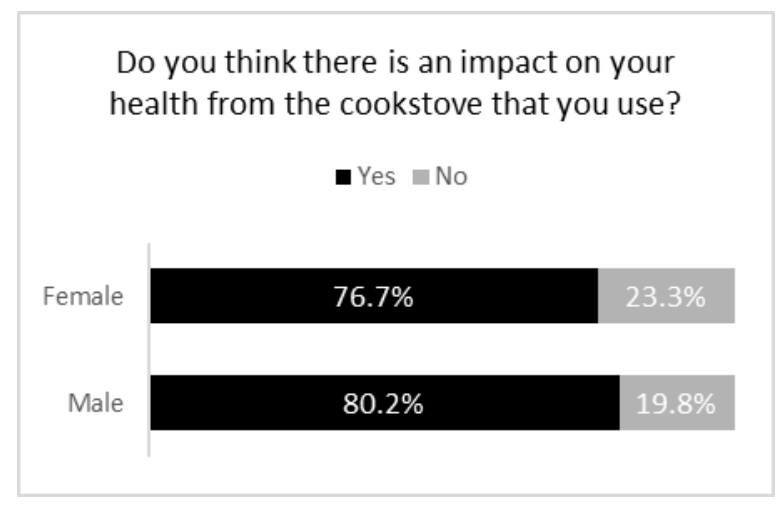

Source: Author's own elaboration

Graph 1. Health impact assessment of unimproved cookstoves by gender.

I do not find any significant effect between number of children on interest or willingness to pay for IBCS (Table 4), counter to findings from previous studies, such as Beyene and Koch (2013), which view children's health as a motivation for the adoption of improved cookstoves.

However, the female identity is highly significant in differentiating consumer attitudes towards unimproved cooking practice. A Welch two-sample t-test showed that the mean value of the "satisfy" dummy (which denotes unsatisfaction with unimproved cookstoves) is significantly higher among the female group.

Table 4. Two-sample t-test on equality of means of "satisfy" between male and female.

\begin{tabular}{llllllll}
\hline \multicolumn{6}{l}{ Hypothesis: True difference in means is not equal to 0 } & & \\
\hline \multicolumn{2}{l}{ Alternative hypothesis: True difference in means is not equal to 0} \\
\hline Groups & $\mathrm{N}$ & $\begin{array}{l}\text { Group } \\
\text { Means }\end{array}$ & $\begin{array}{l}\text { Difference of } \\
\text { Group Means } \\
\text { at 95\% } \\
\text { confidence } \\
\text { level }\end{array}$ & $\begin{array}{l}\text { Degree } \\
\text { of } \\
\text { freedom }\end{array}$ & P-value & Conclusion \\
\hline Male (0) & 2058 & 0.228 & $\begin{array}{l}(-0.15130439, \\
-0.05555704)\end{array}$ & -4.2432 & 591.72 & 0.00002558 & Reject \\
\hline Female (1) & 437 & 0.332 & - & & & \\
\hline
\end{tabular}

Table 5. Two-sample t-test on equality of means of "healthassess" between male and female.

\begin{tabular}{llllllll}
\multicolumn{6}{l}{ Hypothesis: True difference in means is not equal to 0 } & & \\
\hline Alternative hypothesis: True difference in means is not equal to 0 & & & \\
\hline Groups & $\mathrm{N}$ & $\begin{array}{l}\text { Group } \\
\text { Means }\end{array}$ & $\begin{array}{l}\text { Difference of T-statistic } \\
\text { Group Means } \\
\text { at 95\% } \\
\text { confidence } \\
\text { level }\end{array}$ & $\begin{array}{l}\text { Degree } \\
\text { of } \\
\text { freedom }\end{array}$ & P-value & Conclusion \\
\hline Male (0) & 2058 & 0.802 & $\begin{array}{l}(-0.007716762, \\
0.079006344)\end{array}$ & 1.6144 & 610.71 & 0.107 & Fail to \\
Female (1) & 437 & 0.767 & & & & & reject \\
\hline
\end{tabular}

Data also shows that when both unsatisfied with traditional cookstoves, women are less likely to produce a negative health assessment of the practice than men (Graph 2). This means that although women acknowledge a greater burden from the toxic environment of unimproved cooking, they are less able to link that suffering to an assessment of health impact. This could be because that their 
assessment of the burden is experience-oriented in nature and focused on facts such as the unpleasantness of inhaling indoor smoke.

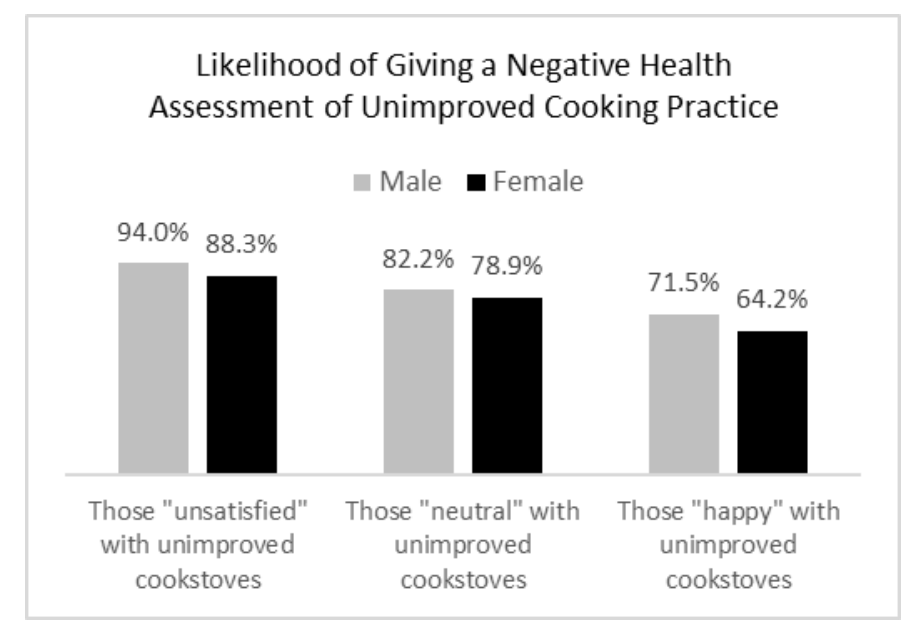

Graph 2. Health impact assessment of unimproved cookstoves by gender and satisfaction.

Source: Author's own elaboration

However, my findings also show that even when respondent is aware of health risks associated with unimproved biomass cookstoves, such health impact awareness is not driving choice behavior towards IBCS among both women and men - the coefficient estimate for the health assessment dummy is insignificant in all regressions on interest and WTP (Table 4). Therefore, there is not enough evidence to support the thesis that inability to give adequate health impact assessment of unimproved cookstoves acts as an explainer for low adoption, since it is inconclusive that such health assessment, if given, would drive adoption.

Instead, the data shows that experience-oriented evaluation of satisfaction is more important than health concerns in determining interest and WTP. The "satisfy" variable is highly significant and positive in all regressions. The fact that women do experience a higher degree of dissatisfaction with traditional unimproved cookstoves is a factor that directly nudges them towards more positive choice behavior than men, despite not resulting in keener realization its negative health impacts.

\section{Power}

Data from the ACCESS survey shows that being a head of household has significant positive effect on both interest and willingness to pay for IBCS adoption, when fixed effects at village level are not included (Table 4). When fixed effects are applied in the estimator equation, headship becomes insignificant and caste becomes significant. The reason for this is not entirely clear.

Data also shows that women are much less likely than men to be head of households - only $7 \%$ of heads of households in the sample are female. Among male respondents, $78.3 \%$ are heads of households whereas only $23.2 \%$ of female respondents are heads of their households. This fact, combined with the apparent power of headship in spurring adoption, gives rise to the suspicion that women are not showing more willingness to shift to IBCS because they cannot rise to the position of head of family which gives them the power to make such choice. 
Indeed, several studies have shown that female-headed households have a more positive choice behavior towards improved cookstoves (Narasimha Rao and Reddy 2007; Lewis and Pattanayak 2012; Brooks et al. 2016; Mamuye 2018). Mohapatra and Simon (2017, p.19), on the other hand, have found a negative relationship between female headship and improved cookstove adoption due to the greater difficulty female heads face than men in dealing with costs; however, they do find a positive effect on adoption from increasing women's intra-household decision-making role.

Data from the ACCESS survey shows that female heads of household do not display significantly different choice behavior towards IBCS adoption than the rest of the sample; only male heads of households do. Moreover, a t-test fails to reject equivalence between the means of interest or WTP between female heads and rest of females; whereas it does find significance difference in interest (at 99\% confidence level) and WTP (at 95\% confidence level) between male heads and the rest of males. Regression analysis also confirms this - when running the OLS regression equation on WTP (Equation 2) within the subset of female respondents, the head of household identity is insignificant; but it is significant at the $90 \%$ confidence level within the male subset.
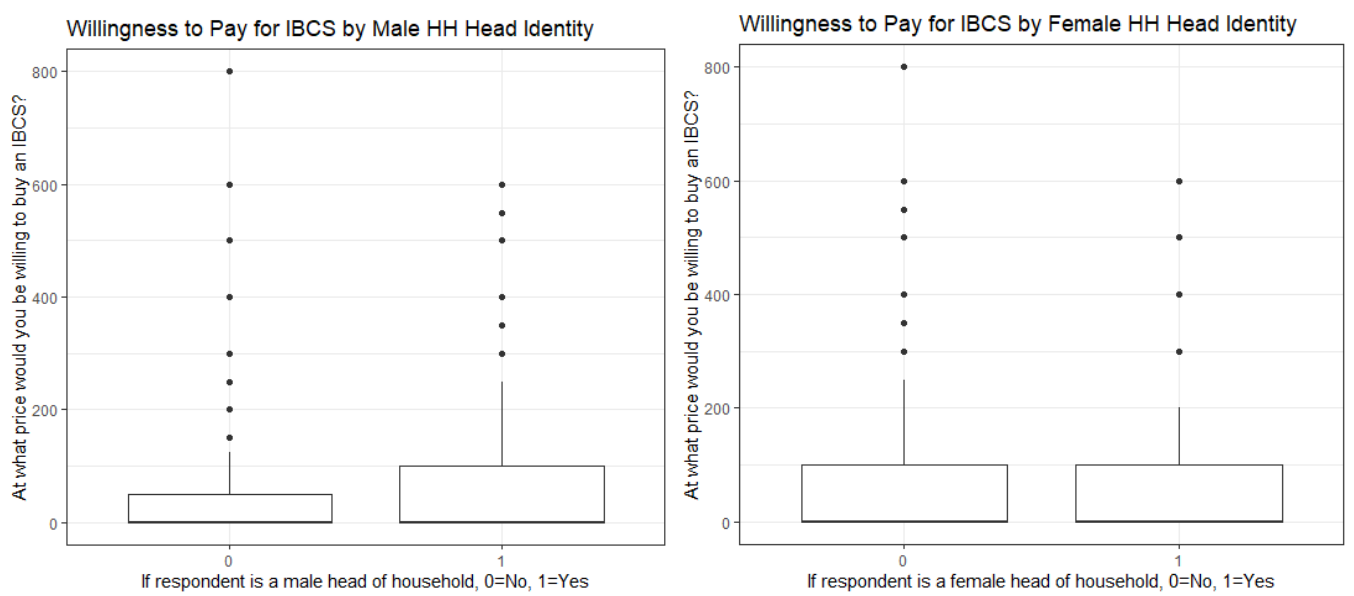

Graph 3. Comparison of WTP between female/male heads of households and rest of sample

Source: Author's own elaboration

Why does the head of household identity cease to influence choice behavior when the head is female? There are several possible explanations: First, the sample size for female heads of households $(n=119)$ is radically small compared to male heads $(n=1613)$. A smaller sample size leads to less efficient estimates of effects.

Second, it is likely that the head of household identity is only significant because it is highly correlated with being male, which is the true driver of positive choice behavior. However, this likelihood is defeated by OLS regression analysis on WTP. When the gender dummy is included as a covariate, the head of household dummy still turns out to be significant (Table 4).

The third explanation is that being male and being head of household both individually have positive effect on demand for IBCS. However, simply having household headship does not directly lead to more positive choice behavior - it only has such effect when it is accompanied by also having the male identity. 
When I compare the choice behavior of female heads of households $(n=119)$ to their male counterparts $(\mathrm{n}=1613)$, a t-test shows that the females heads have plausibly equivalent degree of "interest" as male heads (Table 5). Further, a Kolmogorov-Smirnov test on the distribution of willingness-to-pay figures between the two gender groups of heads of households also shows equivalence from the two groups' willingness to pay for IBCS (Table 6).

Table 6. Two-sample t-test on equality of means of "interest" between male and female heads of HH

\begin{tabular}{|c|c|c|c|c|c|c|c|}
\hline \multicolumn{8}{|c|}{ Hypothesis: True difference in means is not equal to 0} \\
\hline \multicolumn{8}{|c|}{ Alternative hypothesis: True difference in means is not equal to 0} \\
\hline Groups & $\mathrm{N}$ & $\begin{array}{l}\text { Group } \\
\text { Means }\end{array}$ & $\begin{array}{l}\text { Difference of } \\
\text { Group Means } \\
\text { at } 95 \% \\
\text { confidence } \\
\text { level }\end{array}$ & T-statistic & $\begin{array}{l}\text { Degree } \\
\text { of } \\
\text { freedom }\end{array}$ & P-value & Conclusion \\
\hline Male heads $(0)$ & 1613 & 0.348 & \multirow{2}{*}{$\begin{array}{l}(-0.10347688, \\
0.07762599)\end{array}$} & \multirow{2}{*}{-0.28229} & \multirow{2}{*}{135.56} & \multirow{2}{*}{0.7782} & \multirow{2}{*}{$\begin{array}{l}\text { Fail to } \\
\text { reject }\end{array}$} \\
\hline Female heads (1) & 119 & 0.361 & & & & & \\
\hline
\end{tabular}

Table 7. Kolmogorov-Smirnov test on equality of distributions of WTP between male and female heads of HH Hypothesis: The two distributions are equal

\begin{tabular}{llllll}
\hline \multicolumn{4}{l}{ Alternative hypothesis: The two distributions are not equal } & & \\
\hline Groups & $\mathrm{N}$ & $\begin{array}{l}\text { Group } \\
\text { Means }\end{array}$ & D-statistic & P-value & Conclusion \\
\hline Male heads (0) & 1613 & 60.86 & 0.032295 & 0.9998 & Fail to reject \\
\hline Female heads (1) & 119 & 63.32 &
\end{tabular}

My conclusion is therefore that although women are less likely to be heads of their households than men, this is not the reason that keeps them from IBCS adoption. Because when they do actually become heads, they have similar choice behavior towards IBCS as male heads. This could be supporting Millar and Mobarak (2013)'s finding that the constraint on women's choice behavior towards improved stoves comes from male authority, which continues to be present and exerting influence despite female headship.

\section{Access to finance}

Wealth has been demonstrated as the primary determinant of households' decision to adopt improved cookstoves, such as Barnes et al. (1994, p.18)'s review of programs in Africa and Amacher et al. (1992)'s study in Nepal. Access to credit is another dimension of finance that has been proven to drive adoption of improved cooking technology - Edwards and Langpap (2005) showed that households in locations with better access to credit are more likely to adopt gas fuel; Mohapatra and Simon (2015, p.19) found the presence of a bank in the village has positive and significant effects on adoption of improved cookstoves.

Data from the ACCESS survey presents some evidence to support these findings. The third cohort of covariates - "household finances", is the most significant among the three cohorts in determining the willingness to pay. Coefficient estimates reported in Table 4 shows that per additional 10,000 rupees of household savings increase WTP by about 2 rupees; access to a bank increases WTP by about 20 rupees. The relationship between expenditure and WTP appears to be convex - at lower values of 
expenditure, increase in monthly expenditure reduces WTP whereas at higher values, the relationship becomes positive. This could be because increase at lower values of expenditure indicates higher budget constraints but at higher values, as wealth levels increase, budget constraints dissipate and increase in expenditure signals higher purchasing power.

Based on these relationships, gender-based wealth inequalities could offer partial explanation for women's low demand for IBCS. It should be acknowledged that since questions about financials are coded as household-level, respondent-agnostic data points in the ACCESS survey, comparing answers from male and female respondents would not enable us to extract gender differences in access to finance. Therefore, I compare only data from respondents who are female and male heads of households for the following analysis, since in this way there is a clear gender character to the data at household level, assuming that the gender of head of family constitutes a key characteristic of the household.

Male- and female-headed households do not differ significantly in terms of savings and expenditure.
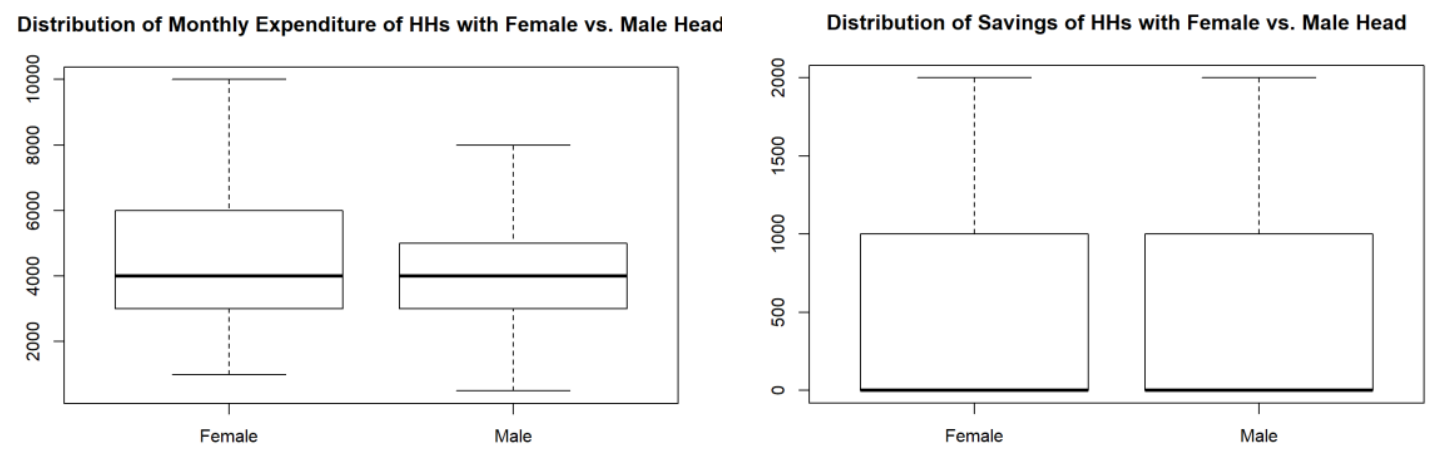

Graph 4. Distributions of monthly expenditure and savings of female- and male-headed households (outliers removed)

Source: Author's own elaboration

Access to credit, though, is mildly worse for female-headed households. $89.9 \%$ of female-headed households have a member of family who owns a bank account whereas $94.5 \%$ of male-headed households do. Among female-headed households which express an interest in IBCS ( $n=43)$, access to credit is even weaker - only $86.0 \%$ of these households are in possession of a bank account, whereas $94.4 \%$ of male-headed households with interest in IBCS ( $n=562)$ have access to a bank.

I also note access to wealth or credit does not increase interest in adoption of IBCS, only willingness to pay. None of the variables from the household finances cohort is significant in regressions on interest. This suggests that interest from the sample population in IBCS is independent of the ability to pay, which is in congruence with Rosenbaum et al. (2015)'s finding that there is revealed preference for improved cookstoves when financial barriers are removed. On the other hand, this also shows that access to finance in itself is insufficient to trigger consumer interest. 


\section{Product}

Previous awareness and usage of IBCS are two factors which have a highly significant and negative relationship with both interest and willingness to pay, without or without village-level fixed effects (Table 4). This is a highly interesting and surprising finding.

\section{Propensity Score Matching}

The fact that awareness of IBCS seems to undermine interest and WTP is counterintuitive. It cannot be ruled out that this is the result of endogeneity, since awareness of IBCS could be correlated with a number of unobservables. Before proceeding to exploring the possible causes of this finding, I need to determine the independent causal effect of awareness on WTP with more certainty.

Setting "IBCSaware" as treatment, I use the Propensity Score Matching technique to match 527 pairs of observations using the following logit estimator equation to predict likelihood of treatment:

Equation 2. Logistical regression estimator equation for predicting selection into treatment ${ }^{2}$.

$$
\operatorname{Logit}(p)=\alpha+\beta \text { Fem }_{v h i}+\gamma E d u_{v h}+\delta \text { Caste }_{v h}+\vartheta \text { Expenditure }_{v h}+\lambda B u s_{v h}
$$

$\left(\mathrm{Y}_{\mathrm{C}}, \mathrm{Y}_{\mathrm{T}}\right) \perp \mathrm{T} \mid \hat{\mathrm{p}}$

Distribution of Propensity Scores

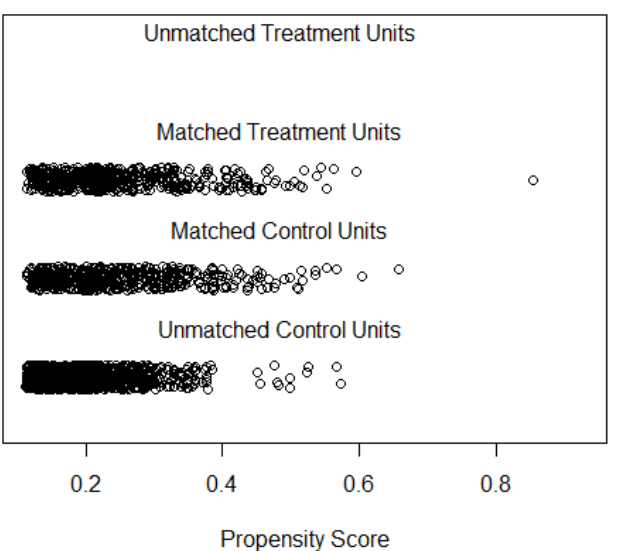

Raw Treated

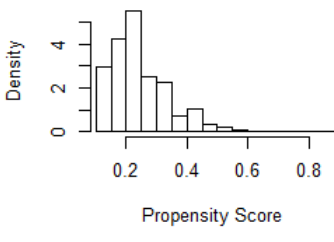

Raw Control

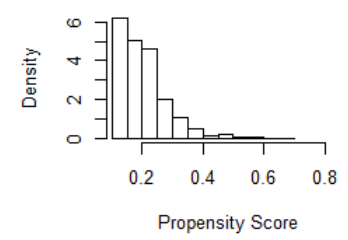

Matched Treated

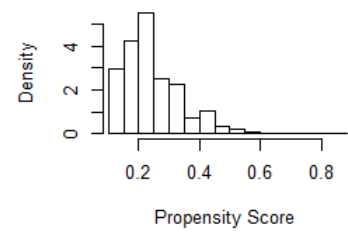

Matched Control

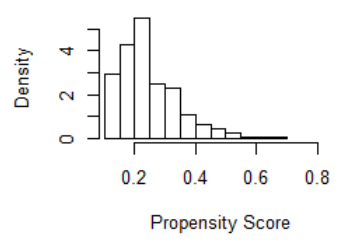

${ }^{2}$ I use the business dummy Error! Reference source not found. (whether household has a business) to proxy effects from social networks on awareness, because including village-level fixed effects to fit the P-score logit estimator equation presents difficulty for matching. All covariates are statistically significant. 
Graph 5. Matched pairs - Distributions and density distributions of P-score within each unit

Source: Author's own elaboration

The matched treatment and control pairs share similar density distributions of p-scores and are wellbalanced in each characteristic. The standardized mean difference (SMD) falls within 0.00 and 0.08 for all 5 variables.

The ranges of P-scores within the treatment and control groups show overlap.

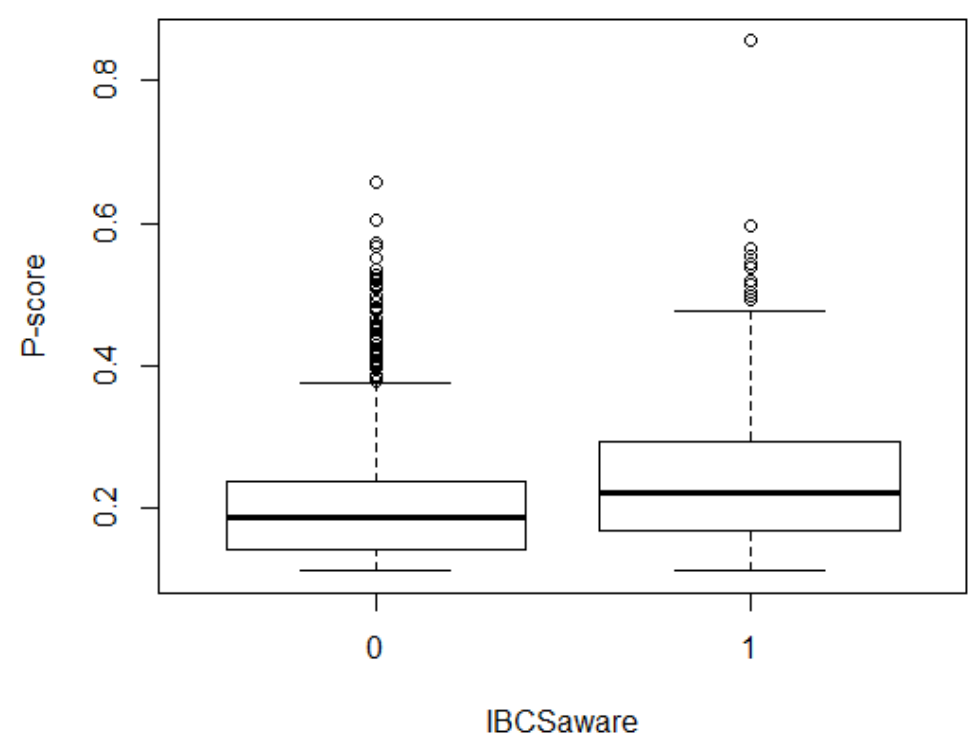

Graph 6. Boxplot of P-scores within treatment and control groups.

Source: Author's own elaboration

The P-score-indexed distributions of WTP of treatment and control groups shows a clear effect of IBCS awareness in undermining WTP (Graph 6). The average treatment effect is estimated at -24 rupees, which is about $41.9 \%$ of the average WTP figure from the sample.
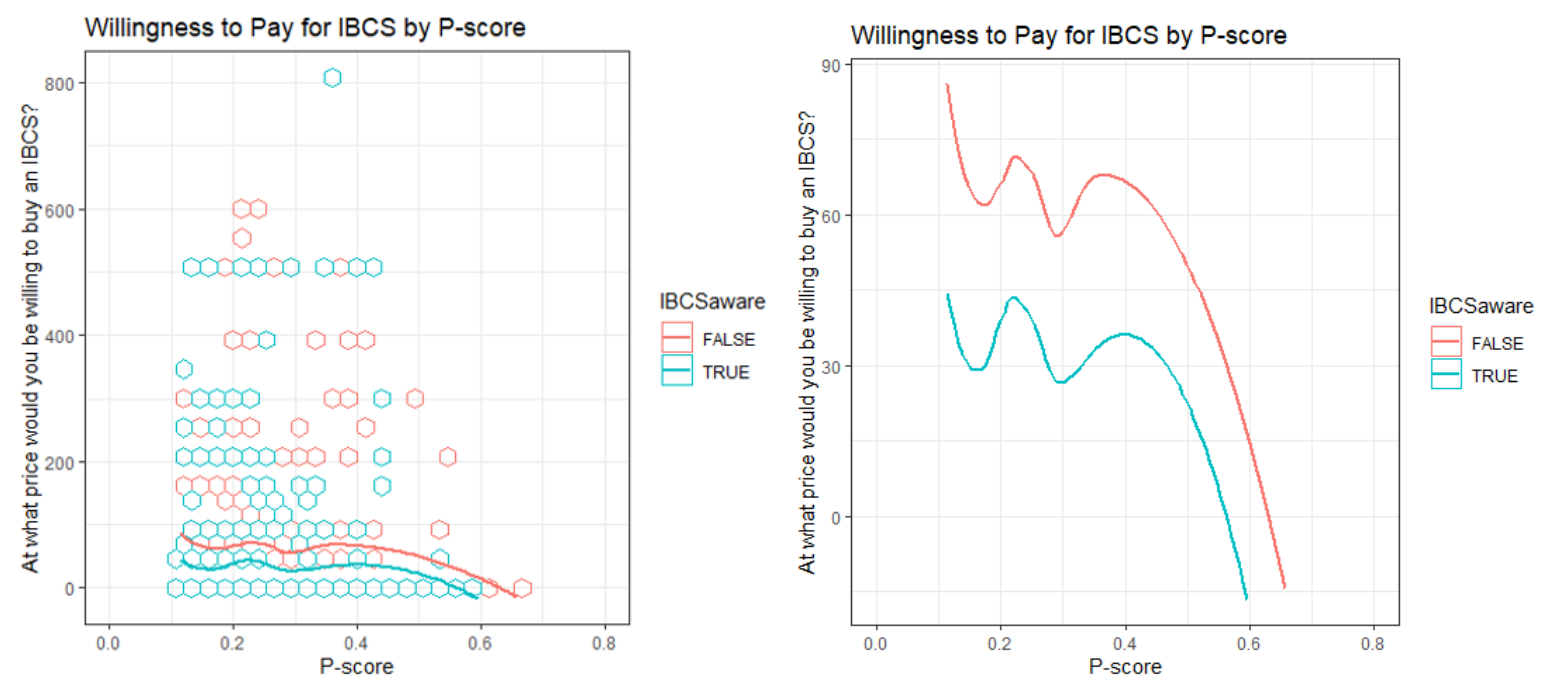
Graph 7. Willingness to pay for IBCS by P-score with data from matched pairs $(n=1054)$

Source: Author's own elaboration

Table 7. OLS regression of WTP on treatment ("IBCSaware”) and Pscore (Matched pairs data only)

\begin{tabular}{ll}
\hline Variable & Coefficient \\
\hline & $-24.47^{* * *}$ \\
IBCSaware $_{\text {vhi }}$ & $(6.40)$ \\
\hline & 14.56 \\
Pscore $_{\text {vhi }}$ & $(33.42)$ \\
\hline
\end{tabular}

Notes:

For each outcome variable, I report the coefficients of interest and their standard errors in parentheses.

Notations on statistical significance: *significant at $90 \%$ confidence level; $* *$ significant at $95 \%$ confidence level; $* * *$ significant at $99 \%$ confidence level

\section{Interpretation}

How do we interpret this finding? It is helpful to refer to the wider literature on health behavior, where scholars have devised frameworks of the constituent components of demand to understand adoption of a health technology. For example, Jenkins and Scott (2007) breaks down households' demand for improved latrines to three stages of adoption - preference, intention and choice in their study of Ghanaian households, and find that the journey to demand breaks most often at the point between intention and choice.

This staged approach to dissecting demand is helpful to determining the exact pain point at which consumers abandons their preference for the new technology, facilitating understanding of the nature of key constraints that hinder adoption. Fitting the ACCESS survey data around this schematic (while rephrasing the former two stages to better characterize the data), we can obtain the following graph which demonstrates the loss of demand through the three stages.

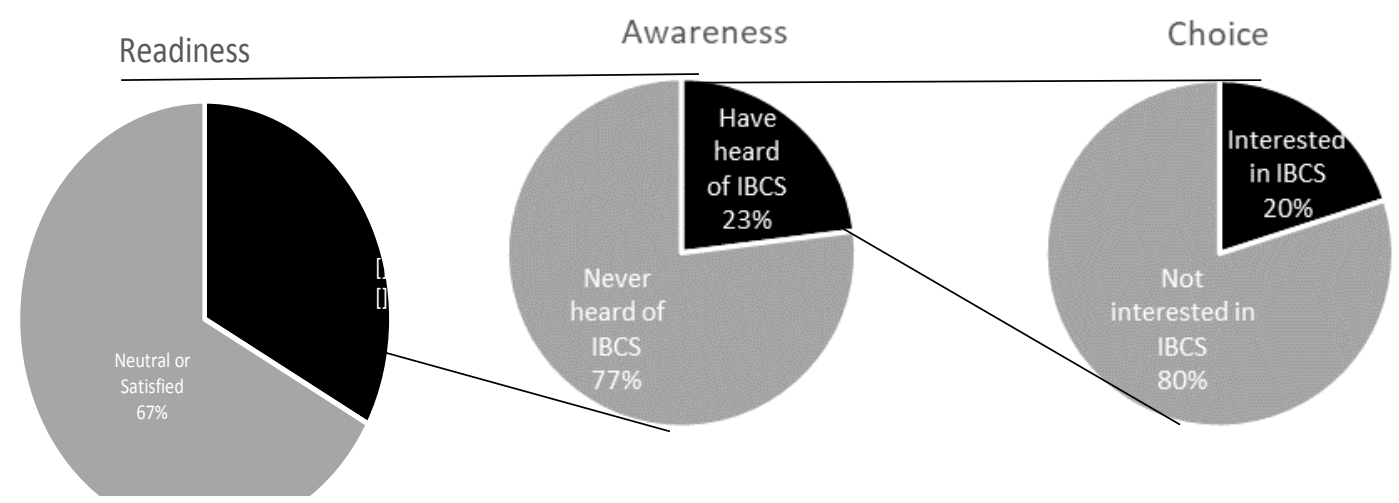


Graph 9. Generation of demand for IBCS among women - data illustration.

Source: Author's own elaboration

Two points of learnings from this exercise is:

- The capture from readiness to awareness is low. Only $23.4 \%$ of women who are unsatisfied with the traditional unimproved cooking practice have heard of IBCS prior to their first introduction to the concept by the survey enumerator. Among women who have prior knowledge of IBCS, $73.6 \%$ are either neutral or happy with their traditional cookstoves. This demonstrates a lack of effective marketing that is informed by research and segmentation of customers.

- Awareness (or usage) does not trigger choice. This is a key observation from the data which runs counter to the expectation of many clean cookstoves programs, which rely on knowledge dissemination about the product as a turn-on for consumer interest.

To explain this, it should be first noted that the "control" case here, as opposed to previous awareness, is a brief and ideally characterized description of IBCS by the enumerator (see Footnote 1) which involves the promise that "they burn biomass more efficiently than traditional stoves, reducing fuel use and smoke" (Aklin et al. 2016, Questionnaire p.18). It is likely that actual IBCS products that Uttar Pradesh consumers are acquainted with have failed to live up to this promise, resulting in consumers' disillusionment about the benefit of IBCS. Those who give their interest and WTP upon hearing the concept of IBCS from the enumerator do not have the opportunity to be disillusioned and therefore give a hypothetical statement of preference that is commensurate with the high expectation of IBCS in the description.

This explanation has support from evidence collected in rural India on failed improved cookstove programs. Khandelwal et al. (2017, p.19)'s fieldwork revealed that the design of improved stoves made it challenging for women to cook with their old recipes and utensils and added to their workload because the IBCS only takes firewood cut into smaller pieces.

\section{Conclusion}

This paper has explored the most likely channels through which Uttar Pradesh women's inclination to adopt IBCS becomes dampened. I found that the most significant reason behind the fact that these women do not display the expected high preference for IBCS is the failure of product. My secondary findings also include that women's assessment of health risks of traditional biomass cookstoves languishes compared to men, there may be inhibiting presence of intra-household patriarchy on choice behaviour and there is mildly worse access to credit for female-headed households. However, none of these factors play as an unambiguous and powerful role as the knowledge of IBCS and previous interaction with an IBCS product in undermining demand.

Some potential shortfalls of this study include 1) An inherent problem with stated preference methods such as contingent evaluation is the WTP figure could be overestimated. The fact that respondents say they are willing to accept a hypothetical price figure does not mean they are able to afford it; 2) Willingness to pay is assumed 0 for those who are not interested. However, it may be in reality less than 0 - that is, a subsidy would be required for converting those who do not express interest into consumers. These two points could be improved by finetuning the survey instrument in future 
fieldwork. Some ramified topics of interest for further research include 1) the exact reason why headship of the household does not give women higher decision power regarding adoption of household technology as much as it gives men; 2) why the significance of caste increases dramatically after village fixed effects are included to estimate interest and WTP.

Revisiting our hypotheses stated earlier, we can summarize the key evidence from this paper as follows:

\begin{tabular}{|c|c|c|c|}
\hline \# & Theme & Hypothesis & Finding \\
\hline 1 & Health & $\begin{array}{l}\text { Women's low demand for IBCS results from } \\
\text { a lack of awareness of health impacts of } \\
\text { unimproved cookstoves OR inability to link } \\
\text { that assessment to demand of IBCS }\end{array}$ & $\begin{array}{l}\text { Not enough evidence to support } \\
\text { causal hypothesis } \\
\text { However, a gender gap in } \\
\text { awareness of health impacts of } \\
\text { unimproved cookstoves is found. }\end{array}$ \\
\hline 2 & Power & $\begin{array}{l}\text { Women's low demand for IBCS results from } \\
\text { the intra-household distribution of decision- } \\
\text { making power which inhibits women from } \\
\text { occupying positions that have a say in IBCS } \\
\text { adoption }\end{array}$ & $\begin{array}{l}\text { Not enough evidence to support } \\
\text { causal hypothesis } \\
\text { However, a gender gap in intra- } \\
\text { household distribution of decision- } \\
\text { making power is found. }\end{array}$ \\
\hline 3 & Finance & $\begin{array}{l}\text { Women's low demand for IBCS results from } \\
\text { lack of access to finance to fund the purchase }\end{array}$ & $\begin{array}{l}\text { Not enough evidence to support } \\
\text { causal hypothesis } \\
\text { However, a gender gap in access to } \\
\text { finance is found. }\end{array}$ \\
\hline 4 & Product & $\begin{array}{l}\text { Women's low demand for IBCS results from } \\
\text { flaws of the IBCS products of which they } \\
\text { have become aware }\end{array}$ & Strongly supported \\
\hline
\end{tabular}

Based on the evidence generated, this paper's recommendation for clean cookstove program implementers is therefore two-fold. First, it is imperative to make sure performance and user experience of the promoted IBCS products are demonstrably superior to unimproved biomass cookstoves, and ramp up marketing to reach more women who show readiness of departure from unimproved cookstoves. Neither of these two conditions appears to have been met in the Uttar Pradesh clean cookstoves market at the time of field research, impeding the transition to the practice of clean cooking which would have satisfied the latent demand for better health from communities documented by survey data, especially from women. Second, we shouldn't be too quick to equate a low rate of take-up of clean cookstoves among women with ignorance or powerlessness on the women's part. As this paper has shown, Uttar Pradesh women are in fact more knowledgeable about clean cookstoves than men as well as more experienced with the market of products. However, they are also rational consumers who can make a decision of non-adoption after interacting with the product and experiencing disappointment. Thus, while acknowledging the roles of sociological factors in inhibiting women's adoption of new household technologies, a market-based approach paying attention to the user-product relationship is also indispensable for understanding women's choice.

\section{Declaration of Interest Statement}

The author declares that she has no conflict of interests. 


\section{References}

Aklin, M.; Cheng, C.; Ganesan, K.; Jain, A.; Urpelainen, J.; Council on Energy, Environment and Water. (2016). Access to Clean Cooking Energy and Electricity: Survey of States in India (ACCESS). Harvard Dataverse, V1.

Amacher, G. S., Hyde, W. F., \& Joshee, B. R. (1992). The adoption of consumption technologies under uncertainty: A case of improved stoves in Nepal. Journal of Economic Development, 17(2), 93105.

Barnes, D. F., Openshaw, K., Smith, K. R., Van der Plas, R., \& Mundial, B. (1994). What makes people cook with improved biomass stoves? Washington, DC: World Bank.

Baumgartner, J., Schauer, J. J., Ezzati, M., Lu, L., Cheng, C., Patz, J., \& Bautista, L. E. (2011). Patterns and predictors of personal exposure to indoor air pollution from biomass combustion among women and children in rural China. Indoor air, 21(6), 479-488.

Beyene, A. D., \& Koch, S. F. (2013). Clean fuel-saving technology adoption in urban Ethiopia. Energy Economics, 36, 605-613.

Bhojvaid, V., Jeuland, M., Kar, A., Lewis, J. J., Pattanayak, S. K., Ramanathan, N., ... \& Rehman, I. H. (2014). How do people in rural India perceive improved stoves and clean fuel? Evidence from Uttar Pradesh and Uttarakhand. International Journal of Environmental Research and Public Health, 11(2), 1341-1358.

Brooks, N., Bhojvaid, V., Jeuland, M. A., Lewis, J. J., Patange, O., \& Pattanayak, S. K. (2016). How much do alternative cookstoves reduce biomass fuel use? Evidence from North India. Resource and Energy Economics, 43, 153-171.

Duflo, E. (2003). Grandmothers and Granddaughters: Old- Age Pensions and Intrahousehold Allocation in South Africa. The World Bank Economic Review, 17(1): 1-25.

Duflo, E. \& Udry, C. (2003). Intrahousehold Resource Allocation in Côte

D'Ivoire: Social Norms, Separate Accounts and Consumption Choices. Economic Growth Center, Yale University.

Edwards, J. H., \& Langpap, C. (2005). Startup costs and the decision to switch from firewood to gas fuel. Land Economics, 81(4), 570-586.

Hart, C., \& Smith, G. (2013). Scaling adoption of clean cooking solutions through women's empowerment: A resource guide. Global Alliance for Clean Cookstoves.

Dasgupta, S., Huq, M., Khaliquzzaman, V., Pandey, K., \& Wheeler, D. (2004). Indoor air quality for poor families: new evidence from Bangladesh. The World Bank.

Khandelwal, M., Hill Jr, M. E., Greenough, P., Anthony, J., Quill, M., Linderman, M., \& Udaykumar, H. S. (2017). Why have improved cook-stove initiatives in India failed?. World Development, 92, 1327.

Lewis, J. J., \& Pattanayak, S. K. (2012). Who adopts improved fuels and cookstoves? A systematic review. Environmental Health Perspectives, 120(5), 637-645.

Malla, M. B., N. Bruce, E. Bates, and E. Rehfuess. 2011. "Applying global cost-benefit analysis methods to indoor air pollution mitigation interventions in Nepal, Kenya and Sudan: Insights and challenges." Energy Policy 39 (12):7518-7529.

Malla, S., \& Timilsina, G. R. (2014). Household cooking fuel choice and adoption of improved cookstoves in developing countries: a review. The World Bank.

Mamuye, F., Lemma, B., \& Woldeamanuel, T. (2018). Emissions and fuel use performance of two improved stoves and determinants of their adoption in Dodola, southeastern Ethiopia. Sustainable Environment Research, 28(1), 32-38. 
Mohapatra, S., \& Simon, L. (2017). Intra-household bargaining over household technology adoption. Review of Economics of the Household, 15(4), 1263-1290.

Miller, G., \& Mobarak, A. M. (2013). Gender differences in preferences, intra-household externalities, and low demand for improved cookstoves (No. w18964). National Bureau of Economic Research.

Mohapatra, S., \& Simon, L. (2015). Intra-household bargaining over household technology adoption. Review of Economics of the Household, 15(4), 1263-1290.

Mukhopadhyay, R., Sambandam, S., Pillarisetti, A., Jack, D., Mukhopadhyay, K., Balakrishnan, K., ... \& Smith, K. (2012). Cooking practices, air quality, and the acceptability of advanced cookstoves in Haryana, India: an exploratory study to inform large-scale interventions. Global Health Action, 5(1), 19016.

Mohapatra, S., \& Simon, L. (2015). Intra-household bargaining over household technology adoption. Review of Economics of the Household, 15(4), 1263-1290.

Narasimha, R. M., and Reddy, B. S. (2007). "Variations in energy use by Indian households: An analysis of micro level data." Energy 32 (2):143-153.

O’Dell, K., Irish, O., Maxted, S. J., \& Peters, S. (2013). Generating consumer demand for clean cookstoves in base-of-pyramid markets: Insights for donors and charitable organizations. Deloitte University Press.

Pal, R. C., \& Rehman, I. H. (2008). Efficient cookstove technology for improving the kitchen environment and livelihood for women in rural India. International Journal of Ambient Energy, 29(3), 137-148.

Person, B., Loo, J. D., Owuor, M., Ogange, L., Jefferds, M. E. D., \& Cohen, A. L. (2012). "It is good for my family's health and cooks food in a way that my heart loves": Qualitative findings and implications for scaling up an improved cookstove project in rural Kenya. International Journal of Environmental Research and public health, 9(5), 1566-1580.

Rehfuess E.A., E. Puzzolo, D. Stanistreet, D. Pope, and N.G. Bruce. 2014. "Enablers and barriers to large-scale uptake of improved solid fuel stoves: a systematic review." Environmental Health Perspective 122:120-130.

Rosenbaum, J., Derby, E., \& Dutta, K. (2015). Understanding consumer preference and willingness to pay for improved cookstoves in Bangladesh. Journal of Health Communication, 20(sup1), 20-27.

Sehgal, M., Rizwan, S. A., \& Krishnan, A. (2014). Disease burden due to biomass cooking-fuelrelated household air pollution among women in India. Global Health Action, 7(1), 25326.

Shankar, A. V., Onyura, M., \& Alderman, J. (2015). Agency-based empowerment training enhances sales capacity of female energy entrepreneurs in Kenya. Journal of Health Communication, 20(sup1), 67-75.

Troncoso, K., Castillo, A., Masera, O., \& Merino, L. (2007). Social perceptions about a technological innovation for fuelwood cooking: Case study in rural Mexico. Energy Policy, 35(5), 2799-2810.

Yu, Fei. (2011). Indoor Air Pollution and Children's Health: Net Benefits from Stove and Behavioral Interventions in Rural China. Environmental and Resource Economics: 1-20. 